\title{
Morphometric diversity and phenotypic relationship among indigenous buffaloes of Banten, Indonesia
}

\author{
DEWI MURNI ${ }^{1,2, \bullet}$, UMIE LESTARI ${ }^{1}$, SRI ENDAH INDRIWATI ${ }^{1}$, ACHMAD EFENDI $^{3}$, NANI MARYANI ${ }^{2}$, \\ MOHAMAD AMIN ${ }^{1, \vee \varphi}$ \\ ${ }^{1}$ Department of Biology, Faculty of Mathematics and Natural Sciences, Universitas Negeri Malang. Jl. Semarang 5, Malang 6514, East Java, Indonesia. \\ Tel./fax.: +62341-551312, `email: dewi.murni.1603419@student.um.ac.id, vemail: mohamad.amin.fmipa@um.ac.id \\ ${ }^{2}$ Department of Biology Education, Faculty of Teacher Training and Education, Universitas Sultan Ageng Tirtayasa. Jl. Raya Jakarta Km. 4, Pakupatan, \\ Serang 42183, Banten, Indonesia \\ ${ }^{3}$ Department of Statistics, Faculty of Mathematics and Natural Sciences, Universitas Brawijaya. Jl. Veteran, Malang 65145, East Java, Indonesia
}

Manuscript received: 3 November 2019. Revision accepted: 7 February 2020

\begin{abstract}
Murni D, Lestari U, Indriwati SE, Efendi A, Maryani N, Amin M. 2020. Morphometric diversity and phenotypic relationship among indigenous buffaloes of Banten, Indonesia. Biodiversitas 21: 933-940. This study aimed to describe the morphometric diversity and phenotypic relationship among indigenous buffaloes of Banten, Indonesia. In this study, 125 buffaloes from six regions were investigated based on 11 morphometric characters. Morphometric diversity was analyzed using multivariate discriminant analysis. The Euclidean genetic distances were used to estimate the phenotypic relationship among the buffalo populations. The indigenous buffaloes of Banten have high morphometric diversity, with a coefficient from 2.83 to $41.43 \%$. The body length and chest circumference can be used as a morphometric marker to determine potential indigenous buffaloes as their high correlation coefficient value (0.506). The Serang district buffaloes have the highest mean of body length and chest circumference, which shows that this population is potential compared to the populations from other regions. The morphometric of buffalo population from Serang City, Cilegon City, Serang District, and Pandeglang District tend to be homogenous. Meanwhile, Lebak and Tangerang District population tends to heterogeneous. According to Euclidean distance analysis, the proximate phenotypic relationship was between Serang and Pandeglang District's buffalo populations. Our results indicated that morphometric diversity and phenotypic relationships of the populations were related to geographical origins and can be used to determine the potential indigenous of buffaloes.
\end{abstract}

Keywords: Banten indigenous buffaloes, morphometric diversity, multivariate discriminant, phenotypic relationship

\section{INTRODUCTION}

Buffalo (Bubalus bubalis) is a commodity that plays an essential role in the achievement of meat sufficiency and contributes significantly to food security (Paraguas et al. 2018). Approximately 3.6 million tons of meat (4.5\%) produced all over the world belong to buffaloes. Asian buffaloes dominate the world by representing 92.52 percent of the buffalo population in the world (194.29 million) (Konuma and Gennari 2014). The population of buffalo in Indonesia is around $1,320,600$ heads ranking in the top ten countries in Asia (Deb et al. 2016). Banten Province is one of the centers of buffaloes development in Indonesia (Maureen and Kardiyanto 2010). The indigenous buffaloes of Banten have great potential to grow as a source of meatproducing. Unfortunately, statistical data showed that the population of Banten buffaloes has declined over the last few years from 123,143 in 2011 to 104,031 in 2015 (General Directorate of Livestock and Animal Health 2015). The decrease in the Banten buffalo population is believed to be able to reduce the genetic resources of buffaloes (Qiptiyah et al. 2019). Therefore, prevention efforts need to be done, such as through morphometric diversity and phenotypic relationship analysis among indigenous buffaloes. Morphometric characterization can generate a complete description of the genetic diversity of buffaloes (Vohra et al. 2015). Morphometric characteristics are the most common criteria for livestock selection (Yilmaz et al. 2013) and can be used as qualifying criteria that demonstrate the potential of livestock (Ç1lek and Petkova 2016). Body analysis has been recorded as a practical approach for investigating the potential of indigenous livestock (de Rezende et al. 2017). Data on buffalo body measurements can play an essential role in livestock preservation (Edouard et al. 2018). A significant difference in buffalo morphometric diversity was reported by Vohra et al. (2015), Dhillod et al. (2017), de Melo et al. (2018), and Paraguas et al. (2018). Unfortunately, these studies were only carried out to investigate the characteristics of the buffalo body size and the correlation among each character. Previous research has not yet studied the distribution and genetic relationship among buffalo populations based on morphometric data, which are necessary to serve as a basis for maintaining the livestock population and establishing a crossbreeding policy (Berthouly et al. 2010).

Multivariate analysis of morphometric characteristics is appropriate to assess genetic diversity within and between livestock populations (Yakubu and Ibrahim 2011). Through this analysis, the distribution of animal populations can be described (Lafi et al. 2016). A multivariate discriminant is a practical approach for analyzing factors to be measured in 
livestock (de Rezende et al. 2017). In addition to assessing genetic diversity, the analysis of morphometric data can also be used to estimate genetic distances within and between livestock populations to reveal their genetic relationship (Yunusa et al. 2013). According to Uffo et al. (2017), the study of genetic relationships among buffalo populations will provide a useful tool for selecting and preserving a genetic resource.

Morphometric diversity and phenotypic relationships among indigenous buffaloes in Banten have not been discussed. Therefore, this study aimed to determine morphometric diversity and phenotypic relationships among indigenous buffaloes in Banten. The distribution of each population based on the data was mapped, and phenotypic distances between each buffalo were also estimated to reveal the phenotypic relationships among the populations. These data are expected to provide a basis for deriving policies on buffalo population enhancement.

\section{MATERIALS AND METHODS}

\section{Study area}

This study was conducted in Banten Province, which is located in the western part of Java Island, Indonesia. The samples were obtained from six out of eight cities/districts of the Banten Province. Sampling was conducted from July 2017 to August 2018 in Serang City, Serang District, Pandeglang District, Lebak District, Cilegon City, and Tangerang District (Figure 1).

\section{Morphometric characteristics and data collection}

Eleven morphometric characteristics were measured in 125 buffaloes from six cities/districts of Banten Province. Morphometric characters that were measured included the length of 1. head, 2. neck, 3. horn, 4. front leg, 5. hind leg, 6. body, 7 . shoulder height, 8 . hind height, 9 . hip-width, 10. chest circumference, and 11. tail (Figure 2).

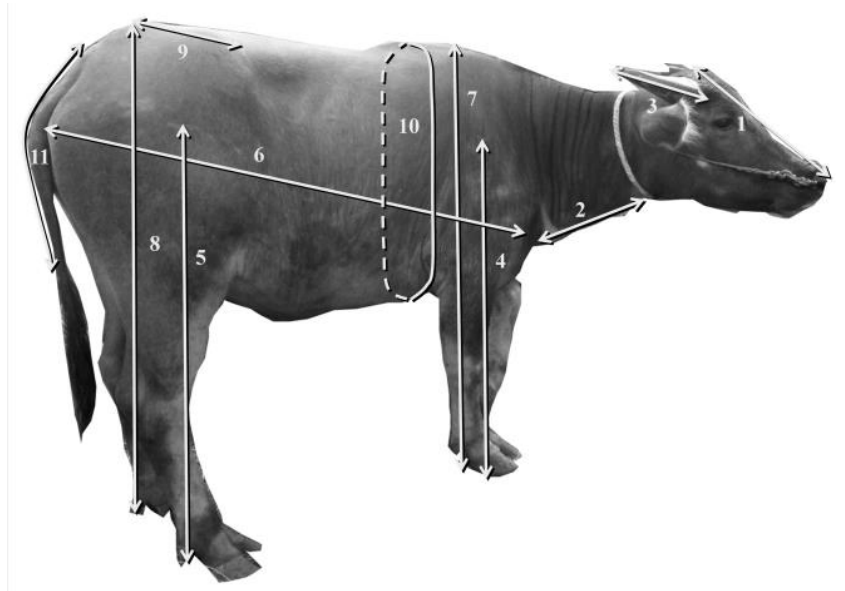

Figure 2. Scheme of morphometrical characters measurement of Banten indigenous buffaloes. Description: Numbers 1-11 are: 1. Head length, 2. Neck length, 3. Horn length, 4. Front leg length, 5. Hind leg length, 6. Body length, 7. Shoulder height, 8. Hind height, 9. Hip width, 10. Chest circumference, 11. Tail length

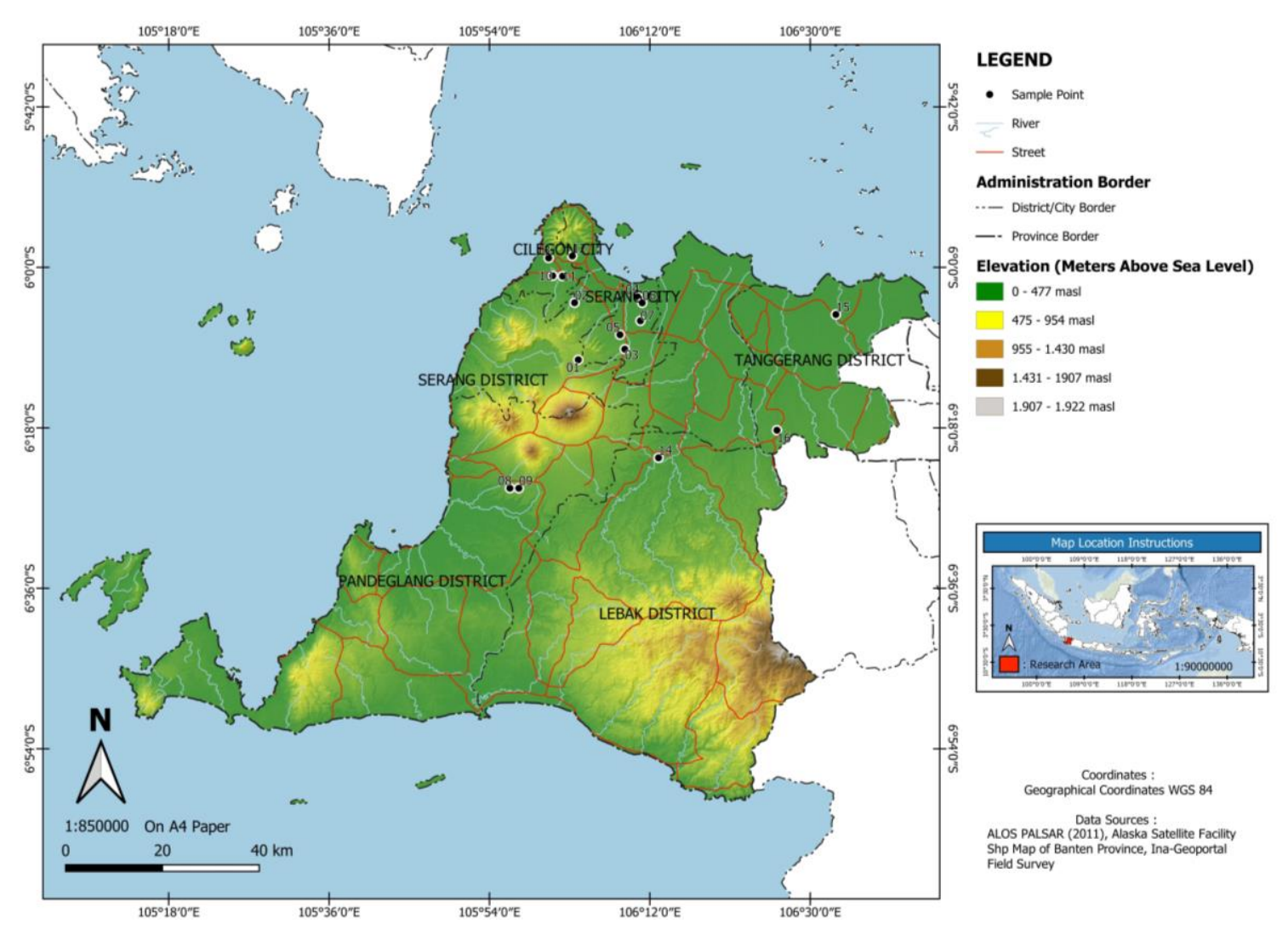

Figure 1. Banten Province map showing six regions where the sample were obtained from 
The head length was measured from the middle position of the head between two horns and the blackened mouth. The length of the neck was measured from the base of the horn to the hump. Horn length was measured at the base until the tip following the direction of the horn growth. Chest circumference was measured in circular right behind the scapula. The length of the tail was measured at the base to the tip of the tail. All of these measurements were recorded by using a Rondo live-stock measuring tape (Vohra et al. 2015; de Melo et al. 2018).

The length of the front leg was measured from the tip of the foot to the shoulder joint. The length of the hind leg was measured from the toe to the elbow joint. Body length was measured from the ischial tuberosity to the tuberosity of the humerus. Shoulder height was measured from the highest part of the shoulder through the back of the scapula perpendicular to the ground. Hind height was measured from the highest part of the hip perpendicular to the ground. The hip width was measured from the vast distance between the two hip joints. All of these morphometric characteristics were measured using a measuring stick. All measurements employed a cm-scale (de Melo et al. 2018; Vohra et al. 2015).

\section{Data analysis}

The morphometric characters were analyzed quantitatively to obtain mean (M), standard deviation (SD), and coefficient of variation $(\mathrm{CV})$. The raw data were transformed before conducting the interrelationship test between each morphometric variable, to avoid the influence of age and gender differences on the morphometrics of buffalo. The difference in the average of the buffalo's morphometric was analyzed using a Duncan multiple range separation of means for univariate variation analysis (ANOVA). The Duncan multiple range test was used as posthoc analyses to determine which pairs of populations are significantly different from each other. Multiple linear regression was conducted to predict the correlation between each morphometric characters. A canonical discriminant analysis was used to identify which morphometric characters are most discriminatory among the populations, and to determine the distribution of Banten indigenous buffalo populations base on morphometric data (Yunusa et al. 2013). Varimax rotation was used to rotate the main components by transforming the components into a simple design (Vohra et al. 2015). Analysis of Euclidean distances was used to construct dendrogram plots (Yunusa et al. 2013). These plots would describe the phenotypic relationships among indigenous populations of Banten buffaloes based on the variations in their morphometric data. All the data analyses were carried out using the SPSS (statistical package for social sciences) 16.0 software (Vohra et al. 2015).

\section{RESULTS AND DISCUSSION}

\section{Morphometrics description of indigenous buffaloes of Banten}

Univariate analysis of variance (ANOVA) revealed a significant difference $(\mathrm{p}<0.05)$ in almost all of the morphometric characteristics with a coefficient of variation ranging from 2.83-41.43\% (Table 1). The lowest coefficient of variation was found in the hind leg length of buffaloes from Lebak district, while the highest coefficient of variation was found in the horn length of buffaloes from the Tangerang District. These coefficients of variation are relatively higher than those of Gojri buffaloes (3.32$19.41 \%$ ) (Vohra et al. 2015), Brazilian buffaloes (3.6516.68\%) (de Melo et al. 2018), and Aceh buffaloes (5.39$16.06 \%$ ) (Eriani et al. 2019).

The Serang district buffaloes had the highest mean of head and body length, hip width, and chest circumference with mean values of $44.52 \mathrm{~cm}, 133.22 \mathrm{~cm}, 47.52 \mathrm{~cm}$, and $199.00 \mathrm{~cm}$, respectively. The indigenous buffaloes have shorter heads compared to Brazilian buffaloes, which have an average of $51.36 \mathrm{~cm}$ in head length (de Melo et al. 2018). The highest neck length was found in the Lebak district population $(45.54 \mathrm{~cm})$. The Cilegon City buffaloes showed the highest average of the front and hind legs length, shoulder-length, and hip height, i.e., $88.37 \mathrm{~cm}$, $94.58 \mathrm{~cm}, 120.84 \mathrm{~cm}$, and $125.84 \mathrm{~cm}$, respectively. The highest average lengths of the horn $(36.37 \mathrm{~cm})$ and tail $(70.16 \mathrm{~cm})$ were found in Pandeglang District. The differences in buffalo body size are associated with genetic and environmental factors as well as nutritional intake and buffalo maintenance system. Serang District farm agroecosystem is a fertile green land that is located at the Valley of Gunungsari Mountain. This type of environment provides good quality food for the buffaloes. Buffalo in Serang District is maintained intensively by being grounded and fed regularly. As a result, the buffaloes can grow better, and their morphometric size can be higher than buffaloes from other regions in Banten. Phenotype is an expression of genetic characters that are influenced by environmental conditions (Yakubu et al. 2010). Variations in the interaction between genetic materials and the environment will result in phenotype variations. Agroecological zones have a significant effect on the differences in livestock body sizes (Edouard et al. 2018). Buffaloes from Serang District have the largest average body size compared to other indigenous buffaloes from Banten. Thus, for animal production, Serang district buffaloes have the potential to be a source of livestock breeds. Larger body size and smaller legs are desirable features for livestock production (de Rezende et al. 2017).

\section{The correlation between each morphometric characteristics of Banten's indigenous buffaloes}

Pearson correlation coefficients illustrating the correlation between buffalo phenotypes are shown in Table 2. 55 correlations showed positive relationships. The correlation coefficient values ranged from-0.012 to 0.915 . The ANOVA results showed that the overall regression models were significant. The regression models is $\mathrm{F}(11.113)=11.412, \quad \mathrm{p}<0.001, \quad \mathrm{R}^{2}=0.526$. Morphometric variables that are significant in determining the diversity of Banten local buffalo are neck length, hip width, chest circumference, and tail length, while other variables proved insignificant. 
The shoulder height and hind height had the highest correlation coefficient value of 0.920 , suggesting that the shoulder height is directly proportional to the buffalo hind height. An increase in shoulder height will be followed by an increase in hind height. The hind leg length and the tail length of the buffalo showed the lowest correlation (0.012). This result is different from de Melo et al. (2018) that found the highest correlation in shoulder width and chest width (0.74). Edouard et al. (2018) also showed different results that buffalo head length and skull width had the highest correlation (0.847).

Furthermore, Vohra et al. (2015) stated that a positive and significant correlation can be found between various morphometric characteristics of livestock. Coefficient correlations values can be used as a standard to determine and select a quality buffalo. Body length and chest circumference showed a high correlation coefficient value of 0.506 . Body length and chest circumference was the lightest correlation with bodyweight for the breed (Shirzeyli et al. 2013). Therefore, both characteristics can be used to estimate livestock body weight (Ç1lek and Petkova 2016; Sarti et al. 2010). Besides, these characters can be used as morphometric markers of the potential of livestock. de Rezende et al. (2017) stated that a combined body measurement can be used as a phenotypic assessment tool and an efficient approach to the assessment of domestic livestock sufficiency.

Canonical discriminant analysis was shown by the eigenvalue and percent of variance (Table 3). Function 1 showed the highest function, with a value of $40.8 \%$. It indicates that this function contributes significantly to the differences in Buffalo morphological characteristics. Eigenvalue indicates how much variation in the dependent variables can be explained by each discriminant function (Hair et al. 2010). The percentage of variance value and eigenvalue indicate the contribution of a function to phenotype differences in populations and the high genetic variability in the function (Ebegbulem et al. 2018).

Neck length was found to be the most discriminating characteristics of Banten buffaloes indicated by the highest canonical value at function 1 (0.996) (Table 4). These characteristics can be used to identify and distinguish phenotypic variations among six Banten indigenous buffalo populations. Characteristics with the highest values were the strongest predictors in determining morphometric diversity among livestock populations (Dauda et al. 2018). On the contrary, Yunusa et al. (2013) found that tail length was the most distinct characteristic of northern Nigerian sheep.

Table 2. Phenotypic correlation among 11 morphometric characteristics in 125 indigenous buffalo of Banten, Indonesia

\begin{tabular}{|c|c|c|c|c|c|c|c|c|c|c|c|}
\hline Correlation & HeL & NL & HoL & FLL & HLL & BL & SH & HН & HW & $\mathbf{C C}$ & TL \\
\hline $\mathrm{HeL}$ & 1.000 & $0.338 * *$ & $0.535 * *$ & $0.459 * *$ & $0.468 * *$ & $0.491 * *$ & $0.491 * *$ & $0.536 * *$ & $0.669 * *$ & $0.423 * *$ & $0.311 * *$ \\
\hline NL & & 1.000 & $0.408 * *$ & 0.104 & -0.009 & $0.255^{* *}$ & $0.218 * *$ & $0.231 * *$ & $0.474 * *$ & 0.125 & $0.497 * *$ \\
\hline $\mathrm{HoL}$ & & & 1.000 & $0.149 *$ & 0.087 & $0.451 * *$ & $0.327 * *$ & $0.338 * *$ & $0.676 * *$ & $0.424 * *$ & $0.47 * *$ \\
\hline FLL & & & & 1.000 & $0.919 * *$ & $0.156^{*}$ & $0.479 * *$ & $0.493 * *$ & $0.371 * *$ & $0.161 *$ & 0.051 \\
\hline HLL & & & & & 1.000 & 0.106 & $0.488 * *$ & $0.472 * *$ & $0.317 * *$ & 0.122 & -0.012 \\
\hline BL & & & & & & 1.000 & $0.453 * *$ & $0.490 * *$ & $0.369 * *$ & $0.506 * *$ & $0.180 *$ \\
\hline $\mathrm{SH}$ & & & & & & & 1.000 & $0.920 * *$ & $0.349 * *$ & $0.402 * *$ & 0.046 \\
\hline HW & & & & & & & & & 1.000 & $0.376 * *$ & $0.555 * *$ \\
\hline $\mathrm{CC}$ & & & & & & & & & & 1.000 & $0.299 * *$ \\
\hline TL & & & & & & & & & & & 1.000 \\
\hline
\end{tabular}

Note: HeL: Head Length; NL: Neck Length; HoL: Horn Length; FLL: Front Leg Length; HLL: Hind Leg Length; BL: Body Length; SH: Shoulder Height; HH: Hind Height; HW: Hip Width; CC: Chest Circumference; TL: Tail Length. The upper asterisk shows the morphometric correlation among the different morphometric characteristics with superscript showing their respective level of significance, i.e., $* *$ means $\mathrm{p}<0.01$ and $*$ means $\mathrm{p}<0.05$

Table 3. Eigenvalue, percent of variance, cumulative and canonical correlation of morphometric characteristics of indigenous buffaloes from Banten, Indonesia

\begin{tabular}{lcccc}
\hline Function & Eigenvalue & $\begin{array}{c}\text { \% of } \\
\text { variance }\end{array}$ & $\begin{array}{c}\text { Cumulative } \\
\text { \% }\end{array}$ & $\begin{array}{c}\text { Canonical } \\
\text { correlation }\end{array}$ \\
\hline $\mathbf{1}$ & 1.913 & 40.8 & 40.8 & 0.810 \\
$\mathbf{2}$ & 1.155 & 24.6 & 65.4 & 0.732 \\
$\mathbf{3}$ & 0.916 & 19.5 & 84.9 & 0.691 \\
$\mathbf{4}$ & 0.421 & 9.0 & 93.9 & 0.544 \\
$\mathbf{5}$ & 0.287 & 6.1 & 100.0 & 0.472 \\
\hline
\end{tabular}

Note: First 5 canonical discriminant functions were used in the analysis
Table 4. Standardized canonical discriminant function coefficients for six Banten, Indonesia indigenous buffaloes, based on 11 morphometric characteristics

\begin{tabular}{lccccc}
\hline $\begin{array}{l}\text { Morphometric } \\
\text { characteristics }\end{array}$ & $\mathbf{1}$ & $\mathbf{2}$ & $\begin{array}{c}\text { Function } \\
\mathbf{4}\end{array}$ & $\mathbf{5}$ \\
\hline Neck length & 0.996 & 0.038 & -0.344 & 0.262 & -0.504 \\
Horn length & -0.371 & -0.259 & 0.305 & -0.754 & 0.119 \\
Hind leg length & -0.273 & 0.372 & 0.614 & 0.166 & -0.614 \\
Body length & -0.014 & -0.320 & -0.219 & 0.341 & 0.620 \\
Shoulder height & 0.106 & -0.183 & 0.033 & -1.693 & 0.148 \\
Hind height & 0.258 & -0.745 & 0.254 & 1.606 & 0.150 \\
Hip width & 0.520 & 0.771 & 0.514 & 0.216 & 0.602 \\
Chest circumference & -0.791 & 0.593 & -0.502 & 0.566 & -0.379 \\
Tail length & -0.284 & 0.363 & -0.424 & -0.430 & 0.093 \\
\hline
\end{tabular}


Canonical discriminant analysis showed that the morphometric characteristics of Serang City, Cilegon, Serang District, and Pandeglang district buffalo populations were grouped in one cluster and overlapped because they tend to be homogeneous. On the contrary, the morphometric characteristics of Lebak and Tangerang District buffalo populations tended to be heterogeneous and different from other populations. Therefore they were separated from the other populations (Figure 3). The finding shows the integration among Serang City, Cilegon City, Serang District, and Pandeglang district buffalo populations. This association is related to geographical factors. As a result, there is a possibility of displacement and mating among the buffalo populations. Due to their near geographic position, two or more populations can be grouped into a single cluster (Abinawanto et al. 2018). Johari et al. (2009) stated that all buffaloes from the nearest regions showed the same position based on canonical structures. This is related to the genetic relationship of the buffaloes, which were assumed to originate from the same ancestor by marriage. In addition to the geographical location of the adjacent areas, the occurrence of intermingling can also be caused by buffalo trading. Serang City is the center of buffalo trade in Banten Province. Twice a week, i.e., on Monday and Thursday, buffalo breeders from Serang city, Serang district, Pandeglang district, and Cilegon city will arrive at the buffalo market in Serang City to sell or buy buffaloes. Each farmer then raises these buffaloes in their respective regions. This has resulted in buffalo mating and gene flow processes. According to Mathias and Mundy (2005), commerce and trade have been an important channel for the movement of livestock. Some of these animals may be used for breeding.

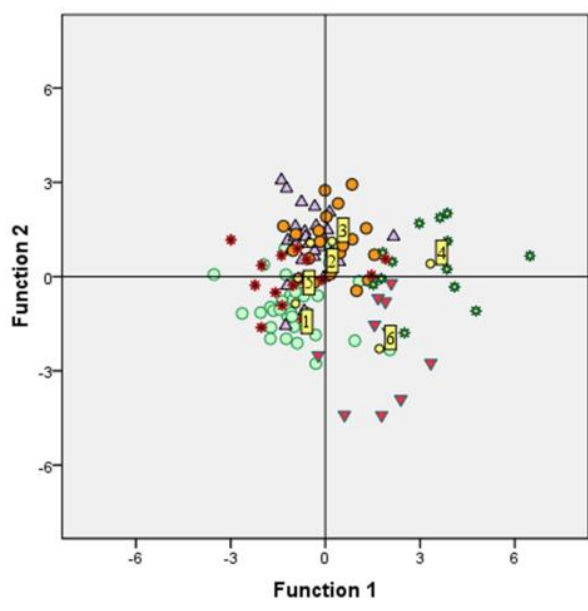

City/District: - 1 Serang City $\triangle 2$ Serang District - 3 Pandeglang District - 4 Lebak District * 5 Cilegon City $\checkmark 6$ Tangerang District - Group Centroid

Figure 3. Banten indigenous buffaloes distribution pattern based on morphometric characteristics
Lebak District and Tangerang District buffaloes tend to have different morphometric characteristics so that the distribution pattern is also different from other cities/districts'. Geographically, Lebak District and Tangerang District areas are located far away from other regions, so the chances to displace or mate buffaloes from these areas with buffaloes from other regions are minimal. According to Zhang et al. (2007), geographical factors and barriers can improve diversity in animal species.

\section{Phenotypic relationships between indigenous buffaloes from Banten}

The smallest phenotypic distance was found between Serang District and Pandeglang District buffaloes (Figure 4), with a value of 0.202 (Table 5). It shows that the Serang and Pandeglang Districts' buffalo populations are closely related based on morphometric characters. Both regions are geographically adjacent to each other. Therefore, free migration and mating can occur between both nearby populations (Johari et al. 2009). The genetic relationships between the buffalo groups are consistent with their biogeographic origins (Winaya et al. 2019). Yunusa et al. (2013) propose that genetic distance is the extent of genomic distinction within and between breed populations. This allows the occurrence of random mating among buffaloes from adjacent areas. Ganbold et al. (2019) stated that livestock populations, which shares a recent common ancestor, have a close relationship. According to Yakubu and Ibrahim (2011), geographical proximity has facilitated the unrestricted and indiscriminate crossbreeding among local livestock populations.

The most significant phenotypic distance was found between the Cilegon City and Lebak District buffalo populations with a value of 0.687. Geographically, both regions are located far apart from each other. Therefore, gene flow cannot occur between them. Winaya et al. (2019) suggest that geographical positions can determine the degree of Indonesian local buffaloes relationships. According to $\mathrm{Wu}$ et al. (2016), geography is one of the critical factors affecting the flow of genes and the processes of evolution. Mwacharo et al. (2007) and Zhang et al. (2007) suggest that there is a significant positive correlation between geographical distance and genetic distance. Thus, geographical distance and geographical barriers will likely result in phenotypic differences in populations.

The long phenotypic distance between Cilegon City and Lebak District buffalo populations can be used as a reference to develop a breeding program to improve hybrid quality. According to Yakubu and Ibrahim (2011), phenotypic distance measures can be used as a baseline for designing a breeding program of the population. Breeding processes between livestock animals with high phenotypic distances may yield appreciable heterosis concerning most economic traits (Bunning et al. 2019). Crossing individuals from distant populations will enhance variability compared to crossing individuals from tightly connected populations. Furthermore, a decrease in gene flow between populations that separated by long distances will maintain the phenotypical variations (Abinawanto et al. 2018). 
Table 5. Euclidean morphometric distance matrix among indigenous buffalo populations from Banten, Indonesia

\begin{tabular}{lccccc}
\hline \multicolumn{1}{c}{ Population } & Serang City & Serang District & $\begin{array}{c}\text { Pandeglang } \\
\text { District }\end{array}$ & $\begin{array}{c}\text { Lebak } \\
\text { District }\end{array}$ & $\begin{array}{c}\text { Cilegon City } \\
\text { Tangerang } \\
\text { District }\end{array}$ \\
\hline Serang City & 0.000 & & & & \\
Serang District & 0.421 & 0.000 & & & \\
Pandeglang District & 0.425 & 0.202 & 0.000 & 0.000 & 0.000 \\
Lebak District & 0.644 & 0.512 & 0.483 & 0.687 & 0.325 \\
Cilegon City & 0.283 & 0.400 & 0.432 & 0.522 & 0.000 \\
Tangerang District & 0.355 & 0.322 & 0.332 & & \\
\hline
\end{tabular}

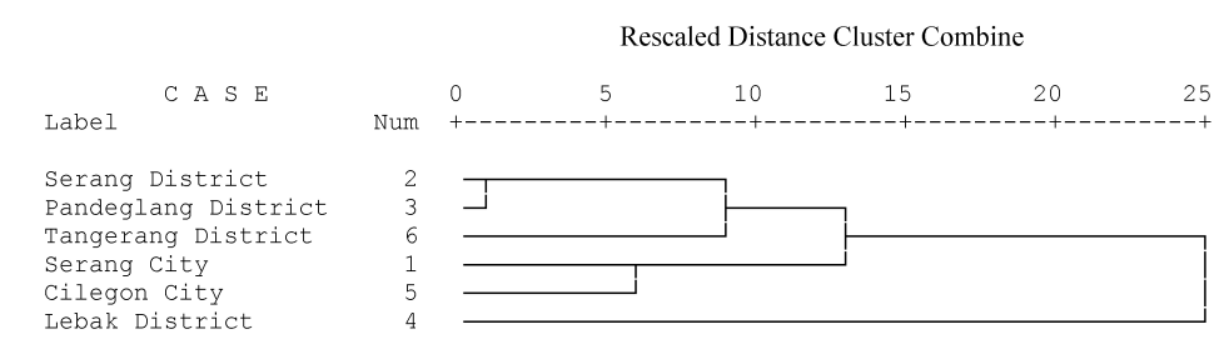

Figure 4. Dendrogram of phenotypic distance among the population of indigenous buffaloes of Banten, Indonesia

In conclusion, reports on morphometric diversity and phenotypic relationships between Banten indigenous buffaloes are still considered novel. The current study showed that there was a high variation in Banten indigenous buffaloes' morphometric characteristics (ranging from 2.83 to $41.43 \%$ ). Positive and significant relationships were also found among the morphometric characteristics of the buffaloes. Body length and chest circumference showed a high correlation coefficient with a value of 0.546 and can be used as a morphometric indicator to determine the potential of Banten indigenous buffaloes. The Serang district buffaloes reported the highest mean of body length and chest circumference, suggesting that this population has more potential compared to other buffalo populations from Banten. The strong phenotypic relationship was found between Serang District and Pandeglang District, while the lowest was found between Cilegon City and Lebak District. The information generated in the study may be useful in identifying potential indigenous buffalo populations for buffalo production improvement and conservation programs. The current morphometric data could also support future decisions concerning managing, preserving, and improving the genetic resources of indigenous buffaloes.

\section{ACKNOWLEDGEMENTS}

This work was supported by the Indonesia Endowment Fund for Education (LPDP), Ministry of Finance of the Republic of Indonesia, through Indonesian Domestic Lecturers' Leading Scholarships (BUDI-DN) by contract number: 219619141081862. This study was also facilitated by the Agriculture Office and Livestock Service Office of
Banten Province regarding the provision of buffalo blood samples. The authors, therefore, would like to thank all of the technical support provided.

\section{REFERENCES}

Abinawanto, Hamidah, Bowolaksono HA, Eprilurahman R. 2018. Biometric of freshwater crayfish (Cherax spp.) from Papua and West Papua, Indonesia. Biodiversitas 19: 489-495.

Berthouly C, Rognon X, Nhu Van T, Berthouly A, Thanh Hoang H, Bed'Hom B, Laloë D, Vu Chi C, Verrier E, Maillard JC. 2010. Genetic and morphometric characterization of a local Vietnamese Swamp Buffalo population. J Anim Breed.Genet 127: 74-84.

Bunning H, Wall E, Chagunda MGG, Banos G, Simm G. 2019. Heterosis in cattle crossbreeding schemes in tropical regions: Meta-analysis of effects of breed combination, trait type, and climate on level of heterosis 1. J Anim Sci 97: 29-34.

Çılek S, Petkova M. 2016. Phenotypic correlations between some body measurements and prediction of body weight of malya sheep. Bulg $\mathrm{J}$ Agric Sci 22: 99-105.

Dauda A, Abbaya HY, Ebegbulem VN. 2018. Application of multifactorial discriminant analysis of morphostructural differentiation of sheep. J Genet Genet Eng 2: 11-16.

de Melo BA, Nascimento IDM, Thayse L, de Lima LG, Chagas F, de Araújo T, Rios RS, Couto ADG, Fraga AB. 2018. Body morphometric measurements in Murrah crossbred buffaloes (Bubalus bubalis). J Appl Anim Res. 2119.

de Rezende, MPG, Ferraz PC, Carneiro PLS, Malhado CHM. 2017. Phenotypic diversity in buffalo cows of the Jafarabadi, Murrah, and Mediterranean breeds. Pesqui Agropecu Bras 52: 663-669.

Deb GK, Nahar TN, Duran PG, Presicce GA. 2016. Safe and sustainable traditional production: The water buffalo in Asia. Front Environ Sci 4: 1-7.

Dhillod S, Kar D, Patil CS, Sahu S, Singh N. 2017. Study of the dairy characters of lactating Murrah buffaloes on the basis of body parts measurements. Vet World 10: 17-21.

Ebegbulem VN, Dauda A, Gabriel PN. 2018. Genetic distance between some local chicken strains in Nigeria: A discriminant analysis. Niger J Anim Sci Technol 1: 100-105. 
Edouard NK, Cyrille KNG, Etienne LNG,Valentine YC. 2018. Multivariate analysis for morphological characteristics of $\mathrm{N}^{\prime}$ dama cattle breed in two Agro-ecological zones of Côte d' Ivoire. Eur Sci J 14: 602-621.

Eriani K, Rahmi R, Jamil I, Rosnizar R, Azhar AL. 2019. Body size characteristics and polymorphism in GH and GHRH genes of Simeulue Buffalo of Aceh, Indonesia. Biodiversitas 20: 236-242

Ganbold O, Lee SH, Seo D, Paek WK, Manjula P, Munkhbayar M, Lee JH. 2019. Genetic diversity and the origin of Mongolian native sheep. Livest Sci 220: 17-25.

General Directorate of Livestock and Animal Health. 2015. Livestock and Animal Health Statistics 2015. Ministry of Agriculture, South Jakarta.

Hair J, Black W, Babin B, Anderson R. 2010. Multivariate Data Analysis, 7Th Edition. Pearson Prentice Hall, New Jersey.

Johari S, Kurnianto E, Hamayanti SWA. 2009. Multivariate analysis on phenotypic traits of body measurement in swamp buffalo (Bubalus bubalis). J Indonesia Trop Anim Agric. 34 (4): 289-294.

Konuma H, Gennari P. 2014. FAO Statistical Yearbook 2014. Asia and the Pacific Food and Agriculture, Bangkok.

Lafi HA, Al-Banna L, Sadder MT, Migdadi HM. 2016. Morphological and morphometrical analysis of Heterodera spp. populations in Jordan. Saudi J Biol Sci 23: 108-114.

Mathias E, Mundy P. 2005. Herd movements, League for Pastoral Peoples and Endogenous Livestock Development. Ober-Ramstadt, Germany.

Maureen C, Kardiyanto E. 2010. Potency of developing buffalo in Banten Province for supporting beef self-sufficiency. In: Seminar dan Lokakarya Nasional Kerbau, Lebak, Indonesia, 24-25 November 2010.

Mwacharo JM, Nomura K, Hanada H, Jianlin H, Hanotte O, Amano T. 2007. Genetic relationships among Kenyan and other East African indigenous chickens. Anim Genet 38: 485-490.

Paraguas AM, Cailipan TPC, Flores EB, Villamor LP. 2018. Morphology and phylogeny of Swamp Buffaloes (Bubalus bubalis) in Calayan Island, Cagayan. Philipp J Vet Anim Sci 44: 59-67.

Qiptiyah M, Pudyatmoko S, Widyatmoko A. 2019. Cytochrome b mitochondrial DNA characteristic from non-invasive samples of wild population Javan Banteng (Bos javanicus d' Alton, 1823). Biodiversitas 20: 350-355.
Sarti FM, Castelli L, Bogani D, Panella F. 2010. The measurement of chest girth as an alternative to weight determination in the performance recording of meat sheep. Ital J Anim Sci 2: 123-129.

Shirzeyli FH, Lavvaf A, Asadi A. 2013. Estimation of body weight from body measurements in four breeds of Iranian sheep. Songklanakarin J Sci. Technol 35: 507-511.

Uffo O, Martínez N, Acosta A, Sanz A, Martín-Burriel I, Osta R, Rodellar C, Zaragoza P. 2017. Analysis of microsatellite markers in a Cuban water buffalo breed. J Dairy Res 84: 289-292.

Vohra V, Niranjan SK, Mishra AK, Jamuna V, Chopra A, Sharma N, Jeong DK. 2015. Phenotypic characterization and multivariate analysis to explain body conformation in lesser-known buffalo (Bubalus bubalis) from North India. Asian Austral J Anim Sci 28: 311-317.

Winaya A, Sukri A, Gofur A, Amin M, Sciences E. 2019. The genetic divergence and phylogenetic relationship of Indonesia swamp buffalo (Bubalus bubalis) based on partial sequences of cytochrome B gene of mitochondrial DNA. Int J Eng Technol 8: 96-100.

Wu Z, Yu D, Li X, Xu X. 2016. Influence of geography and environment on patterns of genetic differentiation in a widespread submerged macrophyte, Eurasian watermilfoil (Myriophyllum spicatum L., Haloragaceae). Ecol Evol 6: 460-468.

Yakubu A, Ibrahim IA. 2011. Multivariate analysis of morphostructural characteristics in Nigerian indigenous sheep. Ital J Anim Sci 10: 8386.

Yakubu A, Salako A, Imumorin I, Ige A, Akinyemi M. 2010. Discriminant analysis of morphometric differentiation in the West African Dwarf and Red Sokoto goats. S Afr J Anim Sci 40: 381-387.

Yilmaz O, Cemal I, Karaca O. 2013. Estimation of mature live weight using some body measurements in Karya sheep. Trop Anim Health Prod 45: 397-403.

Yunusa AJ, Salako AE, Oladejo OA. 2013. Morphometric characterization of Nigerian indigenous sheep using multifactorial discriminant analysis. Int J Biodivers Conserv 5: 661-665.

Zhang Y, Barker JSF, Vankan DM. 2013. The swamp buffalo: Domestication, dispersal, and genetic differentiation. Buffalo Bull 32: 671-674.

Zhang Y, Sun D, Yu Y, Zhang Y. 2007. Genetic diversity and differentiation of Chinese domestic buffalo based on 30 microsatellite markers. Anim Genet 38: 569-575. 
Table 1. Descriptive analysis of morphometric diversity of indigenous buffalo of Banten, Indonesia

\begin{tabular}{|c|c|c|c|c|c|c|c|c|c|c|c|c|c|c|c|c|c|c|}
\hline \multirow{2}{*}{$\begin{array}{l}\text { Morphometric } \\
\text { characters }\end{array}$} & \multicolumn{3}{|c|}{$\begin{array}{c}\text { Serang City } \\
(n=37)\end{array}$} & \multicolumn{3}{|c|}{$\begin{array}{l}\text { Serang District } \\
(n=27)\end{array}$} & \multicolumn{3}{|c|}{$\begin{array}{l}\text { Pandeglang District } \\
(\mathrm{n}=19)\end{array}$} & \multicolumn{3}{|c|}{$\begin{array}{l}\text { Lebak District } \\
\quad(n=13)\end{array}$} & \multicolumn{3}{|c|}{$\begin{array}{l}\text { Cilegon City } \\
(n=19)\end{array}$} & \multicolumn{3}{|c|}{$\begin{array}{l}\text { Tangerang District } \\
(\mathbf{n}=10)\end{array}$} \\
\hline & Mean & SD & $\mathrm{CV}$ & Mean & SD & $\mathrm{CV}$ & Mean & SD & $\mathrm{CV}$ & Mean & SD & $\mathrm{CV}$ & Mean & SD & CV & Mean & SD & $\mathrm{CV}$ \\
\hline $\mathrm{HeL}$ & $39.78^{a}$ & 2.57 & 6.47 & $44.52^{\mathrm{b}}$ & 3.88 & 8.71 & $41.89^{\mathrm{a}}$ & 3.40 & 8.11 & $43.38^{\mathrm{b}}$ & 2.93 & 6.76 & $44.00^{\mathrm{b}}$ & 4.69 & 10.66 & $43.00^{\mathrm{b}}$ & 6.34 & 14.75 \\
\hline NL & $27.11^{\mathrm{a}}$ & 4.38 & 16.17 & $30.70^{\mathrm{b}}$ & 4.24 & 13.81 & $31.74^{c}$ & 5.01 & 15.78 & $45.54^{\mathrm{d}}$ & 8.75 & 19.22 & $25.37^{\mathrm{a}}$ & 7.62 & 30.06 & $31.40^{c}$ & 4.79 & 15.25 \\
\hline $\mathrm{HoL}$ & $27.30^{\mathrm{a}}$ & 9.26 & 33.92 & $34.85^{\mathrm{b}}$ & 10.56 & 30.29 & $36.37^{b}$ & 6.94 & 19.08 & $30.15^{\mathrm{a}}$ & 4.43 & 14.70 & $27.63^{\mathrm{a}}$ & 9.82 & 35.53 & $32.80^{\mathrm{a}}$ & 13.59 & 41.43 \\
\hline FLL & $76.76^{\mathrm{a}}$ & 6.30 & 8.20 & $82.44^{\mathrm{b}}$ & 5.93 & 7.19 & $80.68^{a}$ & 5.29 & 6.56 & $81.38^{\mathrm{b}}$ & 2.90 & 3.57 & $88.37^{c}$ & 6.37 & 7.21 & $83.00^{\mathrm{b}}$ & 11.21 & 13.50 \\
\hline HLL & $80.89^{\mathrm{a}}$ & 5.38 & 6.65 & $86.67^{b}$ & 5.50 & 6.34 & $86.26^{\mathrm{b}}$ & 5.16 & 5.98 & $83.85^{\mathrm{a}}$ & 2.38 & 2.83 & $94.58^{\mathrm{c}}$ & 7.78 & 8.23 & $86.60^{b}$ & 11.19 & 12.92 \\
\hline BL & $124.51^{\mathrm{a}}$ & 15.07 & 12.10 & $133.22^{\mathrm{b}}$ & 21.43 & 16.09 & $116.63^{\mathrm{a}}$ & 5.24 & 4.49 & $123.92^{\mathrm{a}}$ & 6.33 & 5.11 & $119.11^{\mathrm{a}}$ & 11.81 & 9.92 & $132.70^{\mathrm{b}}$ & 14.75 & 11.12 \\
\hline SH & $116.19^{a}$ & 5.33 & 4.59 & $118.48^{\mathrm{a}}$ & 6.93 & 5.85 & $116.21^{\mathrm{a}}$ & 5.83 & 5.01 & $118.08^{\mathrm{a}}$ & 5.39 & 4.57 & $120.8^{\mathrm{a}}$ & 8.92 & 7.38 & $126.50^{\mathrm{b}}$ & 16.02 & 12.67 \\
\hline $\mathrm{HH}$ & $120.32^{\mathrm{a}}$ & 5.80 & 4.82 & $124.56^{\mathrm{b}}$ & 6.92 & 5.56 & $118.53^{\mathrm{a}}$ & 8.06 & 6.80 & $123.62^{\mathrm{a}}$ & 3.62 & 2.93 & $125.84^{\mathrm{b}}$ & 9.17 & 7.28 & $132.00^{c}$ & 16.42 & 12.44 \\
\hline HW & $36.78^{a}$ & 4.17 & 11.34 & $47.52^{\mathrm{d}}$ & 6.86 & 14.43 & $46.11^{\mathrm{c}}$ & 3.00 & 6.50 & $45.92^{\mathrm{a}}$ & 4.77 & 10.38 & $41.84^{\mathrm{b}}$ & 4.81 & 11.50 & $42.70^{\mathrm{b}}$ & 6.57 & 15.38 \\
\hline $\mathrm{CC}$ & $186.32^{\mathrm{b}}$ & 12.94 & 6.94 & $199.00^{c}$ & 20.60 & 10.35 & $179.53^{b}$ & 6.09 & 3.39 & $176.31^{\mathrm{b}}$ & 8.64 & 4.90 & $183.95^{\mathrm{b}}$ & 19.82 & 10.77 & $164.10^{\mathrm{a}}$ & 28.12 & 17.13 \\
\hline $\mathrm{TL}$ & $61.86^{\mathrm{a}}$ & 9.11 & 14.73 & $69.19^{\mathrm{b}}$ & 6.07 & 8.77 & $70.16^{\mathrm{b}}$ & 8.40 & 11.98 & $69.77^{\mathrm{b}}$ & 6.65 & 9.53 & $58.32^{\mathrm{a}}$ & 7.99 & 13.71 & $56.30^{\mathrm{a}}$ & 9.14 & 16.24 \\
\hline
\end{tabular}

Note: HeL: Head Length; NL: Neck Length; HoL: Horn Length; FLL: Front Leg Length; HLL: Hind Leg Length; BL: Body Length; SH: Shoulder Height; HH: Hind Height; HW: Hip Width; CC: Chest Circumference; TL: Tail. abcdMean on the same line with different superscript letters shows a significant difference ( $\left.{ }^{2}<0.05\right)$ with Duncan Multiple Range Test (DMRT), SD: Standard of Deviation, CV: Coefficient of Variation 